\title{
NEUROLOGICAL SIGNS AND SYMPTOMS IN PATIENTS WITH AUTOIMMUNE THYROID DISEASE
}

\author{
Svetlana Miletic Drakulic ${ }^{1}$, Gordana Toncev ${ }^{1}$, Olgica Vrndic ${ }^{2}$ and Snezana Zivancevic Simonovic ${ }^{2}$ \\ ${ }^{1}$ Department of Neurology, Clinical Center Kragujevac \\ ${ }^{2}$ Faculty of Medicine, University of Kragujevac
}

\section{NEUROLOŠKI SIMPTOMI I ZNACI KOD PACIJENATA SA AUTOIMUNSKOM BOLEŠĆU ŠTITASTE ŽLEZDE}

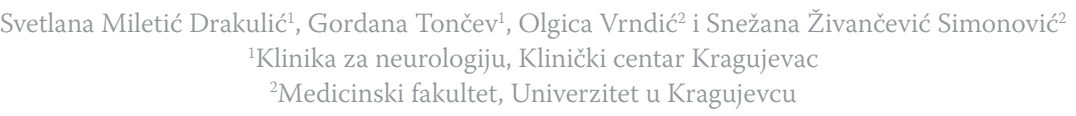

Received / Primljen: 01. 06. 2011.

Accepted / Prihvaćen: 28. 07. 2011.

\section{ABSTRACT}

Neurological and/or psychiatric signs and symptoms can characterizise the clinical picture of encephalopathy associated with autoimmune thyroid diseases and high levels of serum antithyroid autoantibodies. To the best of our knowledge, the literature does not include data on neurological abnormalities in patients with autoimmune thyroid diseases without encephalopathy. Therefore, the aim of this study was to analyse the neurological signs and symptoms that are not associated with a previously identified disease in patients with autoimmune thyroid diseases. This study included 66 patients who were diagnosed with autoimmune thyroid disease. Before the neurological examination, a detailed history of neurological symptoms was obtained for each patient. No neurological symptoms had been present before the test in 47 of 66 patients (71\%). Of the remaining 19 patients (29\%), 13 of 66 (20\%) patients had headache. Among patients with headache, the concentrations of thyroid peroxidise antibodies were slightly higher than in patients without headache, though the difference was not statistically significant ( $p=0.380$, Mann-Whitney test). The patients who took part in this study complained of other neurological symptoms including vertigo (two patients, 3.0\%), tingling of hands (two patients, 3.0\%), transient weakness of one leg (one patient, 1.5\%) and forgetfulness (one patient, 1.5\%). Electroencephalography was performed only in patients with neurological symptoms and was normal in all of these patients. Hashimoto encephalopathy is probably not as rare as predicted, but, among our patients with autoimmune thyroid disease, we did not recognise any patients meeting the required diagnostic criteria for encephalopathy. Some of our patients had headache, which was not linked with any previously identified disease.

Keywords: autoimmune thyroid disease, encephalopathy, thyroid peroxidise, antibodies, headache

\section{SAŽETAK}

Simptomi i znaci neuroloških i/ili psihijatrijskih bolesti (ili: Neurološki i/ili psihijatrijski simptomi) čine kliničku sliku encefalopatije koja je povezana sa autoimunskom bolešću štitaste žlezde $i$ visokom koncentracijom atitireoidnih autoantitela u serumu obolelih. Prema našem saznanju, nema podataka o tome da li postoje diskretni neutrološki poremećaji kod pacijenata sa autominskom bolešću štitaste žlezde bez prethodno dijagnostifikovane encefalopatije.

Cilj našeg rada je da se ispita da li kod obolelih od autoimunske bolesti štitaste žlezde postoje neurološki simptomi $i$ znaci koji se ne mogu povezati sa (objasniti) ranije poznatim bolestima. U ispitivanje je uključeno 66 pacijenata sa dijagnostifikovanom autoimunskom bolešću štitaste žlezde. Pre pregleda uzeta je detaljna anamneza o simptomima koji mogu biti prouzrokovani neurološkim bolestima ispitanika. Bez neuroloških simptoma bilo je 47 (71\%) pacijenata. Od preostalih 19/66 (29\%) pacijenata, 13/66 (20\%) pacijenata imalo je glavobolju. U podgrupi pacijenata sa glavoboljom, koncentracija antitela specifićnih za tireoidnu peroksidazu bila je nešto veća nego kod pacijenata bez glavobolje, ali razlika nije bila statistički značajna ( $p=0.380$, Mann-Whitney test). Od drugih simptoma, pacijenti uključeni $u$ ovo ispitivanje žalili su se na vrtoglavicu (dva pacijenta, 3.0\%), trnjenje ruku (dva pacijenta, $3.0 \%$ ), prolaznu slabost jedne noge (jedan pacijent, 1.5\%) i zaboravnost (jedan pacijent,1.5\%). Elektroencefalografija je uradjena samo kod pacijenata sa neurološkim simptomima i nalazi su bili normalni kod svih ispitanika. Hashimoto encefalopatija je verovatno češća nego što se pretpostavlja, ali kod naših pacijenata sa autoimunskom bolešću štitaste žlezde nije nadjen nijedan pacijent koji bi zadovoljio potrebne dijagnostičke kriterijume. Deo naših pacijenata imao je glavobolju, koja se ne može povezati sa ranije poznatim bolestima.

Ključne reči: autoimunska bolest štitaste žlezde, encefalopatija, tireoidna peroksidaza, antitela, glavobolja

Abbreviations: Abs - autoantibodies, AITD - Autoimmune thyroid diseases , fT4 - free thyroxine , GD - Graves' disease, HE - Hashimoto encephalopathy, HT - Hashimoto's thyroiditis, TPO - thyroid peroxidise , TSH - thyroid stimulating hormone 


\section{INTRODUCTION}

Autoimmune thyroid diseases (AITD) are complex diseases that have cellular and humeral immune responses targeted at the thyroid gland $(1,2,3)$. AITD include Hashimoto's thyroiditis (HT) and Graves' disease (GD), both of which involve the infiltration of the thyroid by $\mathrm{T}$ and $\mathrm{B}$ cells that are reactive with thyroid antigens and production of antithyroid autoantibodies (4, 5, 6, 7). Encephalopathy associated with autoimmune thyroid diseases and high levels of serum antithyroid antibodies was first described in $1966(8,9,10)$ and was named Hashimoto encephalopathy (HE). Since then, more than one hundred cases have been reported, demonstrating a direct link between AITD and the development of encephalopathy $(11,12)$. The prevalence of HE is 2.1/100,000 (13). Neurological and/or psychiatric signs and symptoms are constituents of the clinical picture of HE. The clinical features can be quite variable. The most frequent clinical manifestations include strokelike episodes and a constellation of signs that mimics Creutzfeldt-Jakob disease. The most frequent signs are epileptic seizures, subacute confusion, myoclonus, cognitive impairment or dementia, fluctuations in consciousness, ataxia, tremor, personality disturbances, vertigo, headache, etc. (14). Although rare, HE may be an under-recognised condition because its clinical presentation overlaps with common neurological and psychiatric disorders.

To the best of our knowledge, there isare no data in the literature on neurological abnormalities in patients with AITD without encephalopathy. For that reason, the aim of this study was to analyse the neurological signs and symptoms in patients with AITD that cannot be associated with any previously identified disease.

\section{MATERIAL AND METHODS}

This study was conducted from October-December of 2009 at the Centre of Nuclear Medicine and the Department of Neurology, Clinical Centre Kragujevac, and it was approved by the Ethics Committee of the Clinical Centre Kragujevac.

The study included 66 patients. All blood samples were originally obtained for diagnostic purposes. Blood samples $(10 \mathrm{ml})$ were obtained from each patient and the serum was separated by centrifugation at $2000 \mathrm{rpm}$ for 15 minutes. The sera were frozen at $-20^{\circ} \mathrm{C}$ for storage and then were thawed and assayed. After increased concentrations of thyroid peroxidise autoantibodies (TPO Abs) were found, the patients were informed about the study protocol and were included in the study for further testing. Additionally, concentrations of free thyroxine (fT4) and thyroid stimulating hormone (TSH) were measured from the collected sera.

The concentration of TPO Abs was measured using a radioligand assay (TPO-Ab-CT, Cis-Biointernational, France) according to the manufacturer's instructions. The lower detection limit for this assay was $8 \mathrm{U} / \mathrm{ml}$. The cut off value of autoantibodies specific for thyroid peroxidase was determined based on the manufacturer's recommenda- tions. The measured TPO Ab values were analysed based on a value of $130 \mathrm{U} / \mathrm{ml}$; autoantibody concentrations higher than $130 \mathrm{U} / \mathrm{mL}$ were considered "positive".

The concentration of free thyroxine was measured using a radioimmunoassay (Cis-Biointernational, France). The detection limit for this assay was $0.5 \mathrm{pg} / \mathrm{ml}$, with a reference range of 7-18 $\mathrm{pg} / \mathrm{ml}$.

The concentration of thyroid stimulating hormone was measured using an immunoradiometric assay (IRMA TSH, Zemun, Serbia) with a detection limit of $0.056 \mathrm{mIU} / \mathrm{L}$ and a reference range 0.3-5.5 mIU/L.

A detailed history of symptoms that could be associated with neurological diseases was obtained before the neurological examination. The patient answered questions about his or her symptoms, which may have resembled a cerebrovascular accident, Creutzfeldt-Jakob disease, dementia, epilepsy, myelopathy, damage to the peripheral nervous system and cerebellar syndrome (15). We did not examine mental status. Any symptoms potentially associated with HE were carefully recorded. The neurological examination assessed the cranial nerves, the central and peripheral nervous system and cognitive function. We assessed cognitive function with the mini-mental status exam (MMSE). Impaired cognitive function indicative of dementia (MMSE score of less than 24) was not detected in any of our patients. Two independent neurologists performed the neurological examination on all of the patients. We used a set of clinical criteria for the diagnosis of definite, probable or possible HE, established by Tamagno et al. (16). Mental function was not examined.

Electroencephalography (EEG) was performed only in patients with neurological symptoms. EEG was recorded with a Nihon Kohden 9200J/K apparatus with 25 electrodes placed in accordance with the 10/20 system.

The results obtained were analysed using descriptive statistical methods and the Mann-Whitney test (rank sum test). The tests were conducted using SPSS 10.0 and the MS EXCEL programme.

\section{RESULTS}

This study included 66 patients diagnosed with autoimmune thyroid disease, including 64 women $(97 \%)$ and 2 men (3\%). The mean age was 50 years and the SD was 12.19 years. The youngest patient was 22 years old while the age of the oldest patient was 75 years. The distribution of patients by age is shown in Figure 1.

\section{Figure 1.}

All patients had increased levels of TPO antibodies. The average value of TPO Ab was 4,176 U/mL (minimal concentration $280 \mathrm{U} / \mathrm{ml}$, maximum $12125 \mathrm{U} / \mathrm{ml}$ ), with a SD of 2,887 U/mL. During testing, 52 subjects (9\%) had normal thyroid function, 6 (9\%) had subclinical hypothyroidism, 3 (4\%) had overt hypothyroidism, 2 (3\%) had subclinical hyperthyroidism and 3 (5\%) had overt hyperthyroidism (Figure 2). 
Figure 2.

Of the 66 patients, 47 (71\%) had no neurological symptoms before the test. Of the remaining 19 patients (29\%), $13 / 66$ patients ( $20 \%$ of the total) had headache. One patient had been diagnosed with temporal arteritis, and the other patients had no known neurological or vascular disorders that occur with headache. In the patients with headache, the concentrations of TPO Abs were slightly higher than in the patients without headache, but the difference was not statistically significant ( $\mathrm{p}=0.380$, Mann-Whitney test). Patients who took part in this study also complained of other neurological symptoms. Two patients (3\%), one of whom had diabetes mellitus (DM), complained of vertigo. Two patients (3\%), one of whom had arterial hypertension, also complained of tingling of the hands. One patient (1.5\%) complained of transient weakness of one leg, and one patient (1.5\%) who also had Raynaud's disease and Sjogren's syndrome complained of forgetfulness. The distribution of neurological symptoms is shown in Figure 3. The EEG was normal in all these patients.

\section{Figure 3.}

We found several patients with symptoms of suspected HE: $71 \%$ of patients had no symptoms, $20 \%$ had headaches, $3 \%$ had vertigo, $3 \%$ had tingling of the hands, $1.5 \%$ had transient weakness of the legs and $1.5 \%$ had forgetfulness. The patient with forgetfulness had an MMSE score greater than 24 . Of these patients, none met the required diagnostic criteria for HE.

In our group of patients, 10 of $66(15.1 \%)$ had been treated for neurological diseases. Of these, 4 of 66 (6.1\%) had polyneuropathy (of these, 3 had DM ). Brain infarct had been diagnosed in 4 of 65 (6.1\%). One patient had been diagnosed with a transient ischemic attack of the posterior circulation, and another patient had been diagnosed with multiple sclerosis. It is interesting to note that, among the patients with previous brain infarction, one had hypertension while another patient had diseases of the connective tissue (Sjogren's syndrome and Raynaud's disease), while the remaining two (one of whom was 47 years old at the time of brain infarction) had not had any known systemic or vascular diseases.

\section{DISCUSSION}

The neurological signs and symptoms of 66 patients with autoimmune thyroid disease are presented in this paper. The AITD was confirmed by increased concentrations of TPO Abs in patients' sera.

The most common symptom among our patients was headache, which was found in $20 \%$ of the subjects. The other symptoms were present to a significantly lesser extent. Among all of the patients but one who experienced headache, there were no previously diagnosed diseases that were contributory. Headache as a symptom of posterior reversible encephalopathy syndrome have already

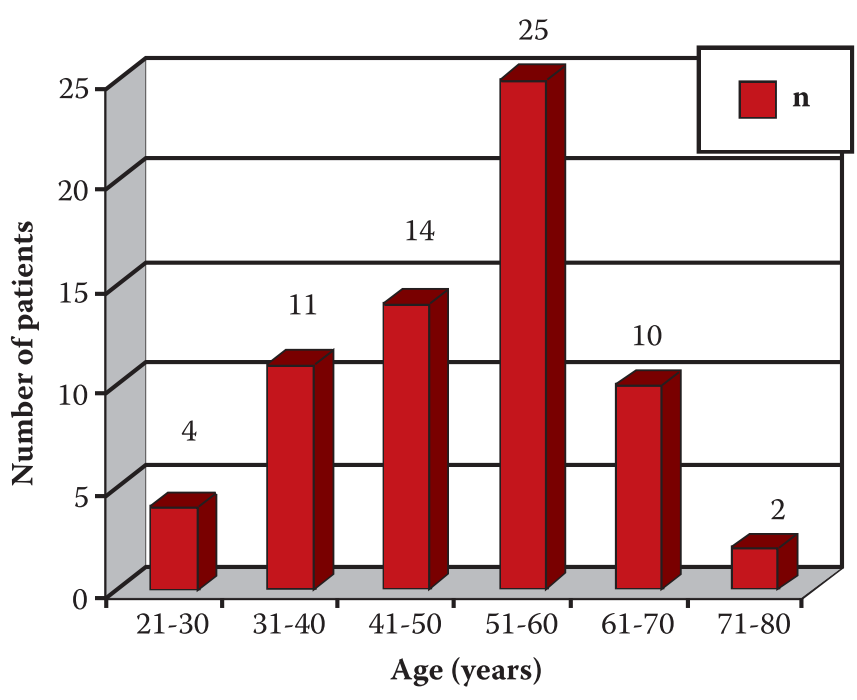

Figure 1. Age of patients with autoimmune thyroid disease.
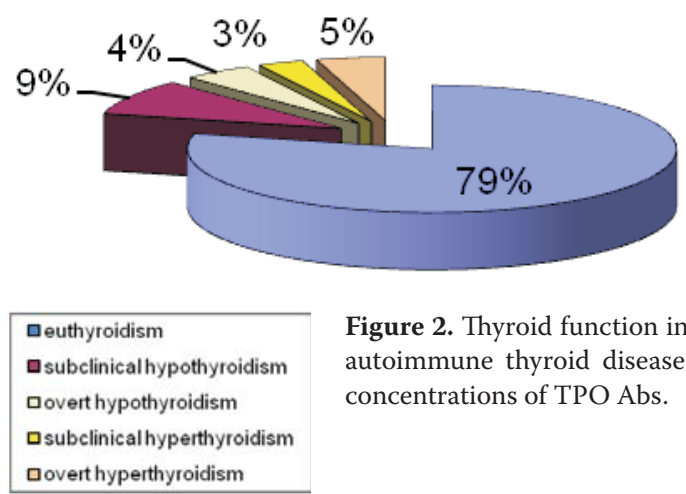

Figure 2. Thyroid function in patients with autoimmune thyroid disease and elevated concentrations of TPO Abs.

口overt hyperthyroidism

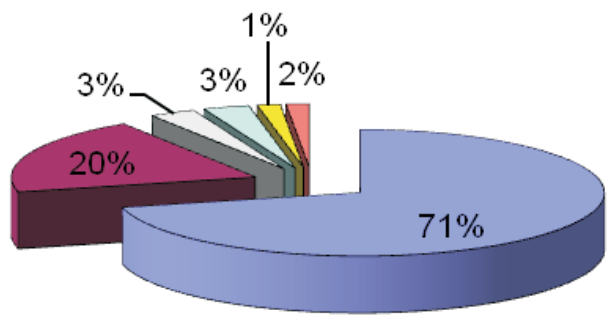

ano synptoms

aheadache

口vertigo

口tingling of hands

口weakness of one leg

aforgetfulness been presented in patients with $\operatorname{AITD}(17,18)$ and in other autoimmune diseases, especially systemic lupus erythematosus $(19,20)$.

Given that there are no data on the frequency of headache in patients without TPO Abs, the frequency of headache found in our patients could be compared only with data from the literature the frequency of head- 
ache in general population. According to the published data $(21,22)$, the frequency of headache varies from $8.4 \%$ to $30 \%$ and depends on many factors that were not examined in our study. Because the percentage of our patients with headache fits the frequency of headache in the general population, we cannot conclude that the headaches in our patients with AITD areis connected with the anti-thyroid autoimmune process. However, because the causes of headache are numerous and have not been thoroughly researched, the possibility that the headache experienced by some of our patients is connected with AITD cannot be excluded.

In patients with headache, the concentrations of TPO Abs were slightly higher than in patients without headache, but the difference was not statistically significant. To the best of our knowledge, there are no data in the literature about the connection between thyroid peroxidase autoantibodies and headache. Although high titres of anti-TPO antibodies were found in almost $100 \%$ of cases of reported Hashimoto encephalopathy, the anti-TPO antibody titre did not correlate with the severity of the disease (23).

Other neurological signs and symptoms were found in one or two patients, and the majority of these could be related to a neurological disease that had been previously diagnosed. For this reason, we will not pay particular attention to those symptoms in this discussion.

HE is probably not as rare as predicted. However, among our patients with autoimmune thyroid disease, we did not recognise any patients thatwho met diagnostic criteria for HE. Some of our patients suffered from headache that was not related to any previously identified disease.

\section{REFERENCES}

1. Živančević-Simonović S, Đukić A, Arsenijević N. and Dimitrijević Lj. Autoimunska bolest štitaste žlezde: patogeneza Gravesove bolesti i Hashimoto tireoiditisa. Medicus 2003; 4(1):21-26.

2. Saxena A, Alport EC, Moshynska O, Kanthan R, Boctor MA. Clonal B cell populations in a minority of patients with Hashimoto's thyroiditis. J Clin Pathol 2004; 57: 1258-1263.

3. McLachlan SM, Nagayama Y, Pichurin PN, et al. The Link between Graves' disease and Hashimoto's Thyroiditis: A Role for Regulatory T Cells. Endocrinology 2007; 148: 5724- 5733.

4. Sikorska HM. Anti-thyroglobulin anti-idiotypic antibodies in sera of patients with Hashimoto's thyroiditis and Graves' disease. J Immunol 1986; 137: 3786-3795.

5. Živancevic-Simonović S, Djukić A, Matović M, Dimitrijević Lj. Autoimunske bolesti štitaste žlezde: in vitro dijagnostika. Medicus 2003; 4(2):23-30.

6. Sinclair D. Clinical and laboratory aspects of thyroid autoantibodies. Ann Clin Biochem, May 2006; 43: 173-183.
7. Vrndić O, Živančević-Simonović S, Dimitrijević $\mathrm{Lj}$, Stanojević M, Đukić A, Arsenijević N. Korelacija koncentracija autoantitela specifičnih za tireoidnu peroksidazu korišćenjem dva radioimunološka testa. Med čas 2008, 42(1) supll 1:28.

8. Brain L, Jellinek EH, Ball K. Hashimoto's disease and encephalopathy. Lancet 1966, 2:512-514.

9. Chong JY, Rowland LP, Utiger RD. Hashimoto encephalopathy: syndrome or myth? Arch Neurol 2003;60:164-71.

10. Vrndic O, Jeftic I, Kostic I, Stanojevic M, Zivancevic Simonovic S. Hashimoto encefalopatija. Med čas 2010: 44:41-44

11. Kothbauer-Margreiter I, Sturzenegger M, Komor J, Baumgartner R, Hess CW. Encephalopathy associated with Hashimoto thyroiditis: diagnosis and treatment. J Neurol. 1996;243(8):585-593.

12. Canto'n A, de Fa 'bregas O, Tintore' M, Mesa J, Codina A, Simo' R. Encephalopathy associated to autoimmune thyroid disease: a more appropriate term for an underestimated condition? J Neurol Sci. 2000;176(1):65-69.

13. Marshall GA, Doyle JJ. Long-term treatment of Hashimoto's encephalopathy. J Neuropsychiatry Clin Neurosci. 2006;18(1):14-20.

14. Pavlovic DM, Pavlovic AM, Lackovic M. Hashimoto encephalopathy - neurological and psychiatric perspective. Arch Biol Sci Belgrade, 61 (3), 383-394.

15. Farracci F, Carnevale A. The neurological disorder associated with thyroid autoimmunity. J Neurol 2006;253:975-984.

16. Tamgno G, Federspil G, and G Murialdo. Clinical and diagnostic aspects of encephalopthy associated with autoiimune thyroid disease (or Haschimitos encephalopathy). Intern Emerg Med I(I) 2006:15-23.

17. Pozo-Rosich P, Villoslada P, Canton A, et al. Reversible white matter alterations in encephalopathy associated with autoimmune thyroid disease. J Neurol. 2002; 249(8):1063-1065,

18. Tateishi Y, Iguchi Y, Kimura K, et al. A case of autoimmune thyroid disease presenting posterior reversible encephalopathy syndrome. J Neurol Sci. 2008;271(1-2):203-206.

19. Kur JK, Esdaile JM. Posterior reversible encephalopathy syndrome-an underrecognized manifestation of systemic lupus erythematosus. $J$ Rheumatol. 2006;33(11):2178-2183.

20. Primavera A, Audenino D, Mavilio N, et al. Reversible posterior leucoencephalopathy syndrome in systemic lupus and vasculitis. Ann Rheum Dis. 2001;60(5):534-537.

21. Wang SJ. Epidemiology of migraine and other types of headache in Asia. Curr Neurol Neurosci Rep 2003;3:104-8.

22. Rasmussen BK. Epidemiology of headache. Cephalalgia 2001;21:774-7.

23. Mocellin R, Walterfang M, Velakoulis D. Hashimoto's encephalopathy: epidemiology, pathogenesis and management. CNS Drugs. 2007; 21(10):799-811. 